\title{
Study on the Influence of Construction Waste Composite Powder Material on Frost Resistance of Concrete
}

\author{
Long Cai ${ }^{a}$, Yong Dai ${ }^{b}$, Huan Zeng \\ Hunan Vocational College of Engineering, Hunan 410000, China \\ a 357685626@163.com, ${ }^{\mathrm{b}}$ 58599281@qq.com, ${ }^{\mathrm{c}}$ 522792979@qq.com
}

Keywords: construction waste; concrete frost resistance; powder material

\begin{abstract}
To explore the effect of composite powder material on the frost resistance of concrete to improve the comprehensive performance of concrete, and to improve the stability and safety of the building has an important role. In this study, the influence mechanism of the composite powder material on the frost resistance of concrete is analyzed. The results show that the frost resistance of C30 concrete is the best and the internal structure is more dense, in order to provide reference and reference for the related people.
\end{abstract}

\section{Preface}

With the rapid pace of urbanization, the construction industry presents a rapid development momentum, the number of construction waste is also increasing, at the present stage, the use of construction waste is mainly concentrated on recycled cementitious materials and cement. The investigation shows that the recycled concrete with building waste composite powder has poor frost resistance, and the anti permeability performance is lower than that of ordinary concrete. Based on this, this study analyzes the influence of construction waste composite powder material on frost resistance of concrete.

\section{Experimental Materials and Schemes}

\subsection{Experimental materials}

In this study, the common silicic acid cement was used as the main experimental material. The common river sand and gravel of A gravel field were collected as building garbage. The composition of composite powder material of construction waste was shown in Table 1 . Through the analysis of the composition of the experimental materials used in this study, it is found that the architectural gravel is mainly composed of $\mathrm{SiO}_{2}, \mathrm{CaO}, \mathrm{Na}_{2} \mathrm{O}, \mathrm{Al}_{2} \mathrm{O}_{3}, \mathrm{Fe}_{2} \mathrm{O}_{3}, \mathrm{MgO}, \mathrm{K}{ }_{2} \mathrm{O}$, LOI and $\mathrm{SO}_{3}$. Among them, the content of calcium oxide is relatively low, which is also the main reason for reducing the activity of construction waste dust. The composition of $\mathrm{SiO}_{2}$ is relatively high, considering that there are a lot of glassy slag in construction waste. The composition ratio of $\mathrm{Al}_{2} \mathrm{O}_{3}$ is relatively high, which indicates that construction waste has certain hydration activity. Table 2 shows that the particle gradation of building debris is poor and the distribution of texture is uneven. This is also an important reason for reducing the activity of dust in construction waste. The physical properties and chemical composition of building waste materials are shown in Table 2 and table 3 respectively.

Table 1 Composition of composite powder material for building waste

\begin{tabular}{cccccc}
\hline $\begin{array}{c}\text { Constituent } \\
\text { elements }\end{array}$ & $\mathrm{SiO}_{2}$ & $\mathrm{CaO}$ & $\mathrm{Al}_{2} \mathrm{O}_{3}$ & $\mathrm{Fe}_{2} \mathrm{O}_{3}$ & $\mathrm{MgO}$ \\
\hline $\begin{array}{c}\text { constituent } \\
\text { ratio }\end{array}$ & 50.04 & 0.94 & 18.64 & 3.07 & 1.67 \\
$\begin{array}{c}\text { Constituent } \\
\text { elements } \\
\begin{array}{c}\text { constituent } \\
\text { ratio }\end{array}\end{array}$ & $\mathrm{Na}_{2} \mathrm{O}$ & $\mathrm{K}{ }_{2} \mathrm{O}$ & $\mathrm{LOI}$ & $\mathrm{SO}_{3}$ & \\
\hline
\end{tabular}


Table 2 physical indicators of composite materials for construction waste

\begin{tabular}{cccccc}
\hline Physical index & $\begin{array}{c}\text { Loss of burning } \\
(\%)\end{array}$ & $\begin{array}{c}\text { Surface area } \\
\left(\mathrm{m}^{2} / \mathrm{kg}\right)\end{array}$ & $\begin{array}{c}\text { Density } \\
\left(\mathrm{kg} / \mathrm{m}^{3}\right)\end{array}$ & $\begin{array}{c}\text { Water } \\
\text { consumption of } \\
\text { standard } \\
\text { consistency (\%) }\end{array}$ & $\begin{array}{c}\text { Particle size }(\mu \\
\mathrm{m})\end{array}$ \\
\hline measured value & 4.58 & 429 & 2.91 & 0.293 & $7-15$ \\
\hline
\end{tabular}

Table 3 chemical composition of composite materials for construction waste

\begin{tabular}{ccccc}
\hline $\begin{array}{c}\text { Constituent } \\
\text { elements }\end{array}$ & $\mathrm{Fe}_{2} \mathrm{O}_{3}$ & $\mathrm{CaO}$ & $\mathrm{Al}_{2} \mathrm{O}_{3}$ & $\mathrm{SiO}_{2}$ \\
\hline $\begin{array}{c}\text { constituent } \\
\text { ratio }\end{array}$ & $2.56-3.38 \%$ & $22.64-25.97 \%$ & $15.28-17.66 \%$ & $43.69-36.41 \%$ \\
\hline
\end{tabular}

\subsection{Experimental scheme}

The combination of this test, as shown in table 4, shows that the output of the powder material is $35 \%, 45 \%$ and $55 \%$, the sand content is $36 \%$, the weight of the cement is $260 \mathrm{~kg}$, the weight of the powder material is $121 \mathrm{~kg}$, the weight of the gravel and sand is $1304 \mathrm{~kg}$ and $652 \mathrm{~kg}$, and the weight of the water is $168 \mathrm{~kg}$. At the same time, in the process of experiment, the frost resistance of concrete under different salt concentration was investigated by using Sodium Chloride Solution with concentration of $2.5,3.5$ and $4.5 \%$ respectively.

Table 4 C30 concrete mix ratio

\begin{tabular}{|c|c|c|c|c|c|c|c|}
\hline \multirow{2}{*}{$\begin{array}{c}\text { Water } \\
\text { cement } \\
\text { ratio (\%) }\end{array}$} & \multirow{2}{*}{$\begin{array}{c}\text { Content of } \\
\text { powder } \\
\text { material } \\
(\%)\end{array}$} & \multirow{2}{*}{$\begin{array}{c}\text { Sand } \\
\text { content } \\
(\%)\end{array}$} & \multicolumn{5}{|c|}{ Material amount $\left(\mathrm{kg} / \mathrm{m}^{3}\right)$} \\
\hline & & & water & cement & Gravel & Sand & $\begin{array}{l}\text { Powder } \\
\text { material }\end{array}$ \\
\hline 0.51 & $20,30,40$ & 35 & 168 & 260 & 1304 & 652 & 121 \\
\hline
\end{tabular}

\section{Results Analysis}

\subsection{Strength test results of different construction waste powder materials}

The results of this study show that the compressive strength of the building garbage concrete is slightly higher than that of the C30 concrete. The 7d compressive strength of concrete is slightly lower when the volume of the building garbage concrete is not more than $30 \%$. When the concrete content of construction waste is increased to $40 \%$, the compressive strength of $7 \mathrm{~d}$ is lower than that of C30 concrete. The possible reasons are: fly ash, brick powder and mineral powder are the main components of composite powder materials for construction waste. When the amount of concrete is small, construction waste composite powder material can make up for the lower part of the strength. With the increase of the content, the internal density of the composite powder material is gradually reduced, and the internal pore is formed under the action of hydration, which makes the compressive strength of C30 concrete decrease ${ }^{[1]}$.

\subsection{Test results of composite materials for construction waste}

In order to explore the effect of construction waste composite powder material on the improvement of concrete activity, this study used the quantitative numerical analysis method of volcanic ash effect as the main research method to evaluate the activity of composite powder material of building waste. The results show that the effect of the ash is more obvious with the increase of the output. In the case of $20 \%$ and $30 \%$, the activity index of volcanic ash is higher, the strength of concrete reaches the peak, and when the output increases to $40 \%$, or the activity index of the ash is reduced, the strength of concrete is also weakened ${ }^{[2]}$.

\subsection{Frost resistance}

The results of the study show that the composite powder material can promote the frost resistance 
of concrete, and the frost resistance is best under the condition of $30 \%$. This is because in the case of $30 \%$, the internal particle size distribution of the composite powder material is more reasonable and the distribution of internal density is more uniform, which can effectively prevent the accumulation of water. In order to optimize the concrete structure and fill the concrete with the powder material without hydration, it effectively increases the compactness of the concrete and reduces the occurrence probability of the seepage phenomenon, and realizes the effective prevention of the freezing water phenomenon.

At the same time, this study fully considered the need to sprinkling deicer salt into the concrete pavement in winter, and using different concentrations of Sodium Chloride Solution to carry out the salt freezing experiment. The results showed that the frost resistance of concrete was obviously destroyed under the coupling of salt and freezing. With the increasing concentration of Sodium Chloride Solution, the rate of freeze-thaw cycle also increases. The reason is that the saturation of concrete increases continuously, which leads to the increase of the internal freezing pressure and the effect of the pressure difference produced by the ice layer, which makes the concrete crack. However, it should be fully realized that there is no significant positive correlation between the increase of Sodium Chloride Solution concentration and the freeze-thaw cycle. When the concentration of Sodium Chloride Solution is 3.5\%, the freezing and thawing cycle is the strongest, and when the concentration of Sodium Chloride Solution is $4.5 \%$, the freeze-thaw cycle effect is the second.

\section{Conclusion}

The composite powder material is helpful to enhance the frost resistance of concrete. In order to achieve the best performance of concrete, the reasonable choice of building waste should be done.

\section{References}

[1] Xue Cuizhen, Shen Aiqin, Lin forest. Effect of composite powder material on strength and impermeability of concrete [J]. Journal of HeFei University of Technology (NATURAL SCIENCE EDITION), 2017, 40 (01): 71-76.

[2] Xue Cuizhen, Shen aqin, Guo Yinchuan. Effect of construction waste composite powder material on frost resistance of concrete [J]. material guide, 2016,30 (04): 121-125. 